\title{
Contributions of Latin American researchers in the understanding the novel coronavirus outbreak: A literature review
}

\author{
Karen Y Fiesco-Sepúlveda ${ }^{\text {Equal first author, } 1}$, Luis Miguel Serrano-Bermúdez ${ }^{\text {Corresp. Equal first author, } 2}$ \\ 1 Epidemiology Program, Faculty of Health Sciences, Universidad Surcolombiana, Neiva, Colombia \\ 2 Bioprocesses and Bioprospecting Group, Universidad Nacional de Colombia, Bogotá D.C., Colombia \\ Corresponding Author: Luis Miguel Serrano-Bermúdez \\ Email address: Imserranob@unal.edu.co
}

This paper aimed to give the visibility of Latin American researchers' contributions to the comprehension of COVID-19; our method was a literature review. Currently, the world is facing a health and socioeconomic crisis caused by the novel coronavirus, SARS-CoV-2, and its disease COVID-19. Therefore, in less than four months, researchers have published a significant number of articles related to this novel virus. For instance, a search focused on the Scopus database on April 10, 2020, showed 1224 documents published by authors with 1797 affiliations from 80 countries. $25.4 \%, 24.0 \%$, and $12.6 \%$ of these national affiliations were from China, Europe, and the USA, respectively, making these regions leaders in COVID-19 research. In the case of Latin America, on April 10, 2020, we searched different databases, such as Scopus, PubMed, and Web of Science, finding that the contribution of this region was $2.7 \pm 0.6 \%$ of the total publications found. In other words, we found 153 publications related to COVID-19 with at least one Latin American researcher. We summarized and processed the information from these 153 publications, finding active participation in topics like medical, social, and environmental considerations, bioinformatics, and epidemiology. 
6 Karen Y Fiesco-Sepúlveda ${ }^{1}$, Luis Miguel Serrano-Bermúdez ${ }^{2}$

$7{ }^{1}$ Epidemiology Program, Faculty of Health Sciences, Universidad Surcolombiana, Neiva,

8 Colombia.

$9{ }^{2}$ Bioprocesses and Bioprospecting Group, Universidad Nacional de Colombia, Bogotá D.C., 10 Colombia.

12 Corresponding Author:

13 Luis Miguel Serrano-Bermúdez

14 Carrera 30 No. 45-03, Bogotá D.C., 11001, Colombia

15 Email address: 1mserranob@unal.edu.co (LMSB) 


\section{Abstract}

17 This paper aimed to give the visibility of Latin American researchers' contributions to the

18 comprehension of COVID-19; our method was a literature review. Currently, the world is facing a health and socioeconomic crisis caused by the novel coronavirus, SARS-CoV-2, and its disease COVID-19. Therefore, in less than four months, researchers have published a significant number of articles related to this novel virus. For instance, a search focused on the Scopus database on April 10, 2020, showed 1224 documents published by authors with 1797 affiliations from 80 countries. $25.4 \%, 24.0 \%$, and $12.6 \%$ of these national affiliations were from China, Europe, and the USA, respectively, making these regions leaders in COVID-19 research. In the case of Latin America, on April 10, 2020, we searched different databases, such as Scopus, PubMed, and Web of Science, finding that the contribution of this region was $2.7 \pm 0.6 \%$ of the total publications found. In other words, we found 153 publications related to COVID-19 with at least one Latin American researcher. We summarized and processed the information from these 153 publications, finding active participation in topics like medical, social, and environmental considerations, bioinformatics, and epidemiology.

\section{Introduction}

Severe acute respiratory syndrome coronavirus 2 (SARS-CoV-2) is a novel virus that mainly affects the respiratory system through the new coronavirus disease 2019 (COVID-19) (Ciotti et al., 2020). COVID-19 has spread quickly; thus, on March 11, 2020, the World Health Organization (WHO) declared it as a pandemic (Hussain et al., 2020). Since the first cases reported in Wuhan, China, in December 2019, until April 20, 2020, SARS-CoV-2 has affected 
38 most countries in the world, with nearly 2.5 million people infected and 170,000 deaths (Johns

39 Hopkins University, 2020). Latin America is no stranger to this reality, totaling approximately

40 100,000 cases and 5,500 deaths, as shown in Table 1 (Johns Hopkins University, 2020).

41 However, these data may be lower than actual numbers because the number of tests per million

42 inhabitants remains low, which is caused by factors such as the limited availability of tests and

43 the difficulty of monitoring people without facilities like indigenous populations, vulnerable

44 groups, and Venezuelan refugees (Oliveira et al., 2020; Torres \& Sacoto, 2020).

45 SARS-CoV-2, as SARS and MERS, belongs to the family Coronaviridae, has a zoonotic origin, 46 and can remain on some surfaces for considerable periods (Ciotti et al., 2020; van Doremalen et 47 al., 2020). Additionally, COVID-19 is a new disease with no yet vaccines or targeted drugs, 48 making the containment of the outbreak difficult (Carnero Contentti \& Correa, 2020). Therefore, 49 the recommendation is the self-isolation to reduce COVID-19 spreading, especially in more 50 susceptible people as older adults or patients with comorbidities (Diaz-Quijano et al., 2020).

51 More general aspects of the current outbreak have been published in review articles according to

52 available information in the moment of publication. These reviews include other zoonotic

53 diseases (such as SARS and MERS), outbreak chronology, virus characteristics, zoonotic links,

54 transmission, diagnosis, disease characteristics, therapeutics \& treatments, prevention,

55 epidemiological surveillance, and control (Ciotti et al., 2020; Cupertino et al., 2020; Huang et

56 al., 2020; Millán-Oñate et al., 2020; Palacios Cruz et al., 2020; Rodriguez-Morales et al., 2020a;

57 Sifuentes-Rodriguez \& Palacios-Reyes, 2020; Siordia, 2020; Wu et al., 2020; Zhu et al., 2020).

58 In the past, during SARS and MERS outbreaks, research focused on coronaviruses increased

59 significantly, which was led by researchers from China and the USA (Bonilla-Aldana et al., 60 2020b). This new outbreak is not an exception because thousands of articles have been published 
61 in less than four months, where China, Europe, and the USA are leaders in the number of

62 publications. In the case of Latin America, it is a region with an increasingly high contribution to

63 science; thus, our question was, what are the contributions of Latin American researchers in

64 understanding this novel coronavirus outbreak? Therefore, our purpose in this review was to

65 highlight the contributions of this region in the comprehension of SARS-CoV-2 and COVID-19.

66 The literature survey consisted of revising and summarizing publications with Latin American

67 researchers. Keeping in mind that several researchers from this region work together with

68 researchers from other continents, we included publications submitted by these types of

69 international research groups. Hence, the relevance of this review focused on finding the

70 research interests of Latin American researchers according to global and regional priorities.

\section{2. Survey methodology}

\section{2.1. Search strategy}

74 We performed the present review following the PRISMA guidelines. The search was done on 75 April 10, 2020, using Scopus, Web of Science, PubMed, ScienceDirect, Wiley, Sage, LILACS,

76 and SciELO databases because they are the main academic literature collections globally and

77 regionally. Other databases like Springer Link were excluded because they do not allow to

78 filtrate by affiliation. The search equation used had ("COVID 19" OR "COVID-19" OR "SARS-

79 CoV-2" OR "SARS CoV 2" OR "SARS-CoV 2" OR "2019-nCoV" OR "2019 nCoV" OR

80 "nCoV-2019" OR "nCoV 2019" OR "hCoV-19" OR "hCoV 19") in all fields and (Argentina OR

81 Bolivia OR Brasil OR Brazil OR Chile OR Colombia OR Cuba OR Ecuador OR Salvador OR

82 Guatemala OR Haiti OR Honduras OR Mexico OR Nicaragua OR Panama OR Paraguay OR 
83 Peru OR Dominicana OR Uruguay OR Venezuela) in affiliation field. We did not consider

84 preprints during the search stage. No interfaces were used in the present literature review.

85

86

87

88

89

90

91

92

93

94

95

96

97

\subsection{Article selection and data extraction}

After the search stage, both reviewers (KYFS and LMSB) removed all duplicated publications, which included a manual revision because some publications were simultaneously in English, Spanish, or Portuguese. Later, we performed a second manual revision to verify that all publications had at least one researcher with a Latin American affiliation. After these two manual revisions, we did not exclude more publications, and final publications were included in the qualitative synthesis. Before the qualitative synthesis, we collected the following information, which was used in the bibliometric analysis: title, authors, journal, DOI, type of publication, national affiliation of Latin American researchers, and topic of publication.

\subsection{Data analysis}

We summarized information from the collected publications according to the type of publication, the topic of publication, and the national affiliation in the "Bibliometric analysis" section. The first purpose of this section was to quantify contributions of the region in the global context, and the contribution by country in the regional context. The second purpose was to classify the publications by topic and type, which allowed us to organize the next sections of this literature review. In the following two sections, "Phylogenetic and molecular understanding" and "medical contributions", we compiled information from research articles and reviews. The last section, called "Additional concerns", was included to highlight contributions not covered in the two 
105 main topics, but discussed in the remaining publications (commentaries, letters to the editor,

106 editorials, communications, perspectives, points of view, and contributions).

107

\section{3. Bibliometric analysis}

109 Following the PRISMA guidelines shown in Figure 1, we found 301 publications in the considered databases; this number decreased to 161 after excluding duplicates. Later, we manually excluded eight additional publications due to affiliations from New Mexico (1) and Pennsylvania (7) were confused with Mexico and Panama, respectively. Therefore, this qualitative analysis included 153 publications, which contained at least one researcher with Latin American affiliation (see Supplementary S1 file for complete information of publications). We highlight that several publications were not exclusively submitted by Latin American researchers, some of which are part of research groups together with North American, European, or Asian researchers. Figure 2 presents the classification of publications by type, where most of them were letters to the editor or commentaries, editorials, and research articles.

Regardless of the number of authors from the same country but different institutions, among all publications, we highlight that 15 of them were submitted by groups in which there were researchers from at least two Latin American countries. Therefore, these publications were counted for each nation involved; thus, these 15 publications have 56 national affiliations. Most of these publications were due to the Latin American Network of Coronavirus Disease 2019COVID-19 Research (LANCOVID-19), which was created to integrate the region around this new outbreak (Rodriguez-Morales et al., 2020d). The remaining 138 publications were submitted

127 by groups in which there were researchers from a single Latin American country. Therefore, 
128 these publications were counted once for the country, disregarding whether they were submitted

129 by one or more researchers with the same national affiliation; in other words, these 138

130 publications have 138 national affiliations. In summary, the 153 publications accounted for 194

131 national affiliations. Figure 3 shows publications by national affiliation, where Brazil had the

132 highest contribution with 80 publications, followed by Colombia, Mexico, and Argentina, with

133 36, 18, and 14 publications, respectively. Conversely, the following Latin American countries

134 had no publications: Cuba, Costa Rica, Dominican Republic, El Salvador, Guatemala, Haiti, and

135 Nicaragua.

136 We did the same search without the affiliation field restriction. We found $1224,615,3538,1841$,

137 665, 48, 2627, and 34 publications in Scopus, Web of Science, PubMed, ScienceDirect, Wiley,

138 Sage, LILACS, and SciELO databases, respectively. Hence, publications with Latin American

139 researchers in these databases, Figure 1, represent $2.9 \%, 3.1 \%, 2.8 \%, 3.3 \%, 2.9 \%, 2.1 \%, 1.6 \%$,

140 and $76.5 \%$ of all publications, respectively. Excluding Scielo, which is a Latin American

141 database, the contribution of the region was $2.7 \pm 0.6 \%$. This low value could be associated with

142 the science gap (gap in science funding, technology, facilities) between the region and the

143 developed countries. However, other possibilities are the late coronavirus appearance in the

144 region (between February and March), as opposed to the initial outbreak (December 2019) and

145 the number of Latin American cases (nearly 4\% world total), as shown in Table 1.

146 Finally, Figure 4 shows the classification of publications by topic, which were medical

147 considerations (surgery recommendations, diagnosis, comorbidities, medical guidelines,

148 dentistry considerations, among others), social and environmental considerations, general aspects

149 (zoonotic links, spreading, origin, disease, surveillance, among others), epidemiological

150 analyses, bioinformatics (molecular and phylogenetic analyses, molecular simulations, genetic 
151 annotations, among others), mental health considerations, search for potential treatments, and

152 meta-analyses. Excluding the general aspects, the remaining topics are shown in the following 153 sections.

\section{Phylogenetic and molecular understanding}

156

157 158

160

161

162

163

164

165

166

167

168

169

170

171

172

173

The researcher with the highest number of research articles was Ph.D. Marta Giovanetti, who has contributed to SARS-CoV-2 understanding through bioinformatic analyses (Angeletti et al., 2020; Benvenuto et al., 2020a; Benvenuto et al., 2020b; Benvenuto et al., 2020c; Benvenuto et al., 2020d; Cleemput et al., 2020; Giovanetti et al., 2020a; Giovanetti et al., 2020b). Her first research focused on a phylogenetic analysis of SARS-CoV-2, finding that among the viruses compared, this virus is closely related to bat-SL-CoVZXC21 (GenBank ID MG772934.1), while the least related is MERS (Benvenuto et al., 2020b). However, Cardenas-Conejo et al. (2020) proposed that SARS-CoV-2 has a closer relation to bat-SL-CoV-RaTG13 (GenBank ID MN996532.1), then, authors suggested first that SARS-CoV-2 is unlikely to come directly from pangolin viruses, and second, that if SARS-CoV-2 has a recombinant origin, this recombination did not happen in ORF1ab. Nevertheless, both Benvenuto et al. (2020b) and Cardenas-Conejo et al. (2020) concluded that the novel virus could come from a bat SARS-like coronavirus isolate, which is in agreement with reports from the GISAID database (Hadfield et al., 2018; Sagulenko et al., 2018).

Subsequent studies of the Giovanetti group found differences in the superficial spike protein S of SARS-CoV-2 through structural analyses, which could give a higher ability to infect humans when compared to other coronaviruses (Benvenuto et al., 2020b). This ability could be attributed to two mutations found in the non-structural protein 2 (nsp2) and nsp3, both originating from a 
174 possible positive pressure (Angeletti et al., 2020). Similarly, evaluating in silico molecular

175 interactions between the human angiotensin-converting enzyme 2 (ACE2) receptor and the spike 176 protein of some coronaviruses, Ortega et al. (2020a) found that SARS-CoV-2 has some modified 177 residues. Such residues could improve the recognition and interaction with the ACE2 receptor, 178 providing SARS-CoV-2 with a higher infectiousness, which is in agreement with another study 179 published simultaneously (Andersen et al., 2020). Likewise, performing in silico molecular 180 interactions, Ortega et al. (2020b) evaluated the interaction between the protease of SARS-CoV-

1812 and some protease inhibitors as a strategy to control COVID-19 infection. The most energetic 182 interactions predicted were using Saquinavir, Lopinavir, and Tipranavir, which are treatments for 183 HIV patients; however, experimentation is required to validate these simulations.

184 In a later study, the Giovanetti group analyzed SARS-CoV-2 mutations through time, finding 185 two variations located in nsp6 and ORF10, which could be caused by a positive selective 186 pressure, leading to a lower protein structure stability and possibly (awaiting for evidence) a 187 higher virulence (Benvenuto et al., 2020a). Cardenas-Conejo et al. (2020) similarly detected 188 variations in nsp6 and eight deleted amino acids in nsp1 from some Japanese virus strains. 189 Although these in silico studies are a first approach and require experimental validation 190 (Ciccozzi et al., 2020), they could also be a first step to aid in identifying treatments or vaccines. 191 Lastly, Giovanetti simultaneously contributed to another research group to develop and validate 192 an open-access tool, called the Genome Detective Coronavirus Typing Tool, which analyzes 193 SARS-CoV-2 genomes to generate new knowledge of COVID-19 outbreak (Cleemput et al., 194 2020).

195 Concerning the sequencing of SARS-CoV-2 genomes to understand this novel coronavirus, some 196 Latin American researchers have contributed to the publication of sequences of isolated strains 
197 from countries such as Chile (Castillo et al., 2020) or Nepal (Sah et al., 2020). Researchers from

198 other countries have also sequenced the genomes of strains from Argentina, Brazil, Chile,

199 Colombia, Ecuador, Mexico, Panama, Peru, and Uruguay, totaling 98 genome sequences until

200 April 20, 2020 (see Supplementary S2 file for detailed information of all sequences). The

201 GISAID database has these 98 sequences collected along with 10,380 others, meaning that Latin

202 American contribution is near 0.94\% (Hadfield et al., 2018; Sagulenko et al., 2018). Table 2

203 summarizes this information by country, showing that Brazil and Mexico have the highest

204 number of sequenced genomes, 52 and 17, respectively. Figure 5 presents some of the Latin

205 American SARS-CoV-2 strains in the phylogenetic tree, evidencing the high heterogeneity

206 among them because they belong to different clades.

207

208 5. Medical contributions

209 5.1. Epidemiological analyses

210 Studies to track first cases in different countries have been performed, such as the case of tracing

211 the first cases of COVID-19 in countries like Italy (Giovanetti et al., 2020b) and Chile (Castillo

212 et al., 2020) using phylogenetic analyses. Both studies found that the first cases came from China

213 and Europe since S and G variants of SARS-CoV-2 were detected. In the case of Italy, a reentry

214 from Germany was detected (Giovanetti et al., 2020a). Tracing of imported cases to other Latin

215 American countries has also been performed using strategies such as data recovery of

216 international flights from the most affected countries to Brazil (Candido et al., 2020), or

217 recompilation of epidemiological data from hospitals in Bolivia (Escalera-Antezana et al., 2020).

218 Both studies concluded that the first imported cases came from Europe, specifically from Italy

219 and Spain. Moreover, other bioinformatics tools have been used to contribute to epidemiological 
220 understanding. For example, a Bayesian phylogeographic reconstruction suggested that Wuhan 221 was effectively the outbreak epicenter on November 25, 2019, spreading later to other Chinese 222 regions (Benvenuto et al., 2020c).

223 Additionally, the geo-positioning of some cases and the heterogeneity of the outbreak progress 224 among countries, with demographic similarities, have been reported (de Figueiredo et al., 2020; $225 \mathrm{Xu}$ et al., 2020). Other epidemiological studies have been done to predict the COVID-19 226 spreading (Benvenuto et al., 2020d; Córdova-Lepe et al., 2020; González-Jaramillo et al., 2020; 227 Manrique-Abril et al., 2020), which concluded that containment strategies are required to avoid 228 overspreading in countries like Chile and Colombia. Similarly, Kraemer et al. (2020) analyzed 229 the effect of mobility in China before and after the sanitary containment of Wuhan in the 230 COVID-19 spreading in this country; they demonstrated that decreasing mobility favors the 231 reduction of COVID-19 spreading.

232

\subsection{Meta-analyses performed}

Latin American researchers have also published meta-analyses of clinical, laboratory, and image data from reported COVID-19 cases (Borges do Nascimento et al., 2020; Rodriguez-Morales et al., 2020b). On the one hand, the meta-analysis submitted by Rodriguez-Morales et al. (2020b) on February 29, 2020, used 19 articles with 2,874 patients for quantitative analyses. On the other hand, the meta-analysis of Borges do Nascimento et al. (2020), submitted six days later, employed 61 studies with 59,254 patients. Both revisions included the most common symptoms as well as typical abnormalities observed in chest radiographs and computed tomographies,

241 which were like other respiratory illnesses and viral pneumonia, making it difficult to distinguish

242 from them (Borges do Nascimento et al., 2020). Oxygen support in critical patients was also 
243 analyzed, where Borges do Nascimento et al. (2020) suggested that excluding the non-invasive

244 ventilation usage since no evidence supports its benefits.

245 Regarding lethality, the most affected population (81\%) was the older group (60 years or more),

246 but additional information is required to understand the COVID-19 impact on other continents

247 because most of the data used in these meta-analyses came from China. Therefore, meta-analyses

248 using Latin American cases would also be ideal for determining how COVID-19 could affect this

249 region, which has some differences, such as lower average age or higher exposure to respiratory

250 infections than other regions like Europe (Amariles et al., 2020a). A third meta-analysis was

251 found, which suggested that it could be possible to predict if a patient with COVID-19 can

252 present complications. Lagunas-Rangel (2020) suggested that complications are related to high

253 levels of neutrophil-to-lymphocyte ratio (NLR) and low levels of lymphocyte-to-C-reactive

254 protein ratio (LCR).

255

256 5.3. Search for potential treatments

257 Concerning treatments to respiratory issues, Khoury et al. (2020) revised respiratory therapies

258 for COVID-19 patients using cell-based treatments such as mesenchymal stem cells (MSCs),

259 derivatives, or other cells, which have shown positive results in pre-clinical models of influenza.

260 Conversely, they argued that there were few coronavirus studies, such as the case of seven

261 COVID-19 patients in Beijing treated with MSCs, who showed apparent improvements up to 4

262 days after treatment, but lacked detailed information (Leng et al., 2020). Therefore, after a

263 systematic search in databases, Khoury et al. (2020) found 27 ongoing treatments with 1,287

264 patients. The authors also highlighted the importance of following ethical protocols for these

265 types of treatments. 
266 Besides the previously mentioned review, since currently there are no approved treatments or 267 vaccines for COVID-19, other revisions have summarized the development of clinical trials for

268 COVID-19 treatments. This is the case of the search made by Rosa \& Santos (2020), who looked

269 for ongoing clinical trials in Clinicaltrials.gov. The authors used some constraints in their search, 270 such as low cost, reduced time to reach markets, existing pharmaceutical supplies, or the 271 possibility to combine with other drugs. In total, 24 clinical trials were found, most of them in 272 clinical phases 2,3 , or 4 , with a scheduled end in 2020. These ongoing clinical trials are using 273 chloroquine, hydroxychloroquine, human immunoglobulin, remdesivir, arbidol, lopinavir, 274 ritonavir, oseltamivir, darunavir, cobicistat, interferons, carrimycin, danoprevir, xiyanping, 275 favipiravir, thalidomide, vitamin C, methylprednisolone, pirfenidone, bromhexie, bevacizumab, 276 fingolimod, and traditional Chinese medicines (TCM).

277 Similarly, Serafin et al. (2020) searched for new treatments for coronaviruses like SARS-CoV, 278 SARS-CoV-2, and HCoV-OC43 in PubMed, SCOPUS, and Web of Science databases. The 279 drugs found as SARS-CoV-2 treatments are captopril, chloroquine, clomipramine, disulfiram, 280 enalapril, hydroxychloroquine, mefloquine, metformin, nitazoxanide, remdesivir, and 281 teicoplanin. This review highlighted positive results using chloroquine, hydroxychloroquine, 282 teicoplanin, and hydroxychloroquine in conjunction with azithromycin. Finally, Rosales283 Mendoza (2020) suggested that a potential treatment with biotechnological origin could be 284 produced using plant species as hosts.

\subsection{Medical considerations}

287 Most medical articles studied populations at risk and comorbidities, also provided

288 recommendations and guidelines for medical personnel. Rascado Sedes et al. (2020) developed a 
289 contingency plan that allows an optimal response of the intensive care units (ICU) to the

290 pandemic. The plan considers possible scenarios, the need for human and technical resources,

291 communication and information, optimized use of resources, and personal protective equipment

292 (PPE).

293 Healthcare workers, emergency room physicians, anesthesiologists, dentists, ophthalmologists,

294 head and neck surgeons, maxillofacial surgeons, and otolaryngologists are among the most

295 vulnerable ones because they perform procedures that can aerosolize secretions (Kowalski et al.,

296 2020). According to several studies, articles, and protocols, Boccalatte et al. (2020) summarized

297 recommendations related to PPE, mandatory use of protective suits, head covers, eye protection,

298 mask, gloves, and N95, FFP2, or PAPR masks, personnel training, and techniques or

299 manoeuvers for different medical practices.

300 Concerning surgeries, although there is no information about to translate risks to the operating

301 room team during such procedures to COVID-19 patients, the recommendation is to postpone

302 them (Cohen et al., 2020; Ducournau et al., 2020). The situations in which a delay in the surgical

303 procedure may affect the patient, such as some oncologic or organ transplant surgeries, surgery

304 must be performed following strict preventive measures. In the case of unpostponable abdominal

305 surgeries, a laparotomic operation with regional anesthesia should be preferred (Carneiro et al.,

306 2020; Cohen et al., 2020; Correia et al., 2020; Quintão et al., 2020). Other articles summarized

307 protocols and recommendations for hand (Ducournau et al., 2020), head and neck (Kowalski et

308 al., 2020), and urologic surgeries (Puliatti et al., 2020).

309 Researchers have also performed literature reviews concerning populations with higher risk due

310 to comorbidities. First, Hussain et al. (2020) focused on patients with diabetes mellitus and

311 COVID-19. They summarized the different determinants that associate this pathology with 
312 greater severity and death, as well as the importance of multidisciplinary medical management.

313 The authors mentioned that COVID-19 could cause pancreatic damage, which could affect

314 patients with diabetes. Likewise, the positive effects of hydroxychloroquine and chloroquine on

315 diabetic patients were mentioned, such as reducing insulin degradation tending to normalize

316 glucose levels. Therefore, in case hydroxychloroquine or chloroquine is administered,

317 antidiabetic drug doses should be readjusted to avoid hypoglycemic events. The authors also

318 mentioned the necessity to continue studying in these patients the chronic inflammation, immune

319 response, coagulation activity, and vascular permeability, as well as whether hyperglycemia or

320 hypoglycemia can alter the virulence of SARS-CoV-2, or whether the virus itself interferes with

321 insulin secretion or glycemic control. All this information will be needed to propose adequate

322 clinical treatments.

323 Likewise, Puliatti et al. (2020) considered the effect of SARS-CoV-2 in different organs of the

324 urinary tract. They highlighted that ACE2-positive cells (target of SARS-CoV-2 spike proteins)

325 have been found in these organs, which could have a high risk of affectation, even leading to

326 death, which explains the kidney damage experimented in some COVID-19 patients. Similarly,

327 chronic hemodialysis patients are also at particular risk due to their immunosuppression status,

328 advanced age, and comorbidities coexistence. Vega-Vega et al. (2020) summarized the

329 recommendations for these patients proposed by three international organizations: Center for

330 Disease Control and Prevention (CDC), the Spanish Society of Nephrology, and the Latin

331 American Society of Nephrology and Hypertension, to which were added suggestions of some

332 experts. Some recommendations are the proper definition of cases, guidelines for patients and

333 family, scrutiny of suspicious COVID-19 cases and their management within hemodialysis units,

334 PPE employment, and sanitation of surfaces and devices. 
335 Another group at risk mentioned by researchers is related to critical COVID-19 patients who

336 need assisted ventilation. Some authors recommend taking into account some considerations

337 before using high-flow nasal oxygen therapy, non-invasive ventilation, or extracorporeal

338 membrane oxygenation (ECMO), the latter being a treatment that no all medical centers can

339 afford. First, if the medical center has adequate protection levels for health workers from exhaled

340 air dispersed, and second, the impact of treatment on acute respiratory distress syndrome

341 (ARDS) (Bartlett et al., 2020; Ñamendys-Silva, 2020a; Ñamendys-Silva, 2020b). Similarly,

342 Chica-Meza et al. (2020) summarized conventional and non-conventional respiratory therapies

343 in critical COVID-19 patients, including recommendations and considerations. Finally, surveys

344 have been performed to identify COVID-19 impacts in patients at risk, such as pediatric patients

345 with cancer (Hrusak et al., 2020), but the information is still limited; however, the

346 recommendation is to follow the same medical practices described previously.

\section{5.5. Mental health considerations}

349 Mental health care must be considered, given that quarantine can cause boredom, loneliness, 350 anger, anxiety, depression, and stress. Patients and health workers should have mental health 351 services (Carvalho et al., 2020b; Lima et al., 2020). In especial when more people can be

352 affected by mental issues during the outbreak than by the outbreak itself (Ornell et al., 2020), 353 and previous outbreaks have caused post-traumatic stress disorder (PTSD) in health workers

354 (Torales et al., 2020).

355 Concerning performed studies on mental issues, first, Fonseca et al. (2020) established

356 recommendations for patients with schizophrenia. Among recommendations are an adequate

357 identification of COVID-19 symptoms, prevention of worsening of psychiatric symptoms, 
358 relapses due to the closed environment, fear of disease and isolation, use of telemedicine,

359 promoting adherence to antipsychotic medication regimens, reducing emotional distress, hygiene

360 practices, and family support. Finally, Carvalho et al. (2020a), using questionnaires to Brazilians,

361 investigated whether extroverted and conscientious people are engaged with the containment

362 measures implemented during the COVID-19 pandemic. They found that extroverted people

363 seem to lack commitment to containment measures, while people with conscientiousness

364 personality tend to follow recommendations. Therefore, at least in Brazil, strategies for

365 extroverted people should be proposed to avoid they become transmission vectors. However, the

366 idiosyncrasy is similar throughout Latin America; thus, these strategies should be required in the 367 entire region.

\section{Additional Concerns}

\subsection{Social and environmental concerns}

371

372

373

374

375

376

377

378

379

380

- Telemedicine should be considered as an alternative to patient attention to avoid COVID-19 spreading. However, this strategy is limited because of the scarce existence of telemedicine systems; thus, social media could be used (Assis Machado et al., 2020; Quintão et al., 2020).

- Elachola et al. (2020) highlighted that there are no prevalence and effectiveness studies on using facemasks related to the COVID-19 outbreak. This information could be useful in providing recommendations about their usage. However, based on past outbreaks, the evidence did not show positive or negative effects when the population used facemasks (Stern et al., 2020).

- Since the first COVID-19 cases reported in Latin America, fake news and misinformation have increased, where even treatments with potential health affectations have been proposed, 
as in the case of using chloroform or ether as alleged COVID-19 treatments (Lana et al.,

382 2020; Martins \& Santos, 2020). Additionally, information should be verified, avoiding panic spreading, which has caused panic buying of supplies and medications (Cuan-Baltazar et al., 384 2020).

385

- The quick COVID-19 spreading in different regions and countries could cause that health

386 workers to become overwhelmed, therefore training new personal, although challenging, is a 387 necessity that could help to attend the current outbreak. Additionally, the pharmacy

388 workforce should be prepared as they are the first ones to attend possible cases of infection 389 (Amariles et al., 2020b; Aruru et al., 2020; Haines et al., 2020).

- Countries with low or middle incomes, such as Latin American countries, may have already 391 saturated their health systems. Hence, the COVID-19 outbreak could oversaturate them 392 (Carneiro et al., 2020), which can be exacerbated by the lack of government preparation and 393 social policies, such as the Ecuadorian case (Hallo et al., 2020).

394 - Based on events that occurred with the "Diamond Princess" cruise, alternatives should be 395 proposed to quarantine people from other cruises and illegal immigrants entering a country 396 (Sawano et al., 2020).

397 - Due to the current outbreak, many activities have been interrupted, which joined the 398 socioeconomic limitations of vulnerable groups, could lead to food insecurity in these 399 populations, who even have no access to clean water (Oliveira et al., 2020).

- Knowing that COVID-19 has a zoonotic origin, One Health approach has taken relevance, 401 which seeks integrative studies where the health of humans, environment, and animals are 402 considered to understand the virus environment, allowing the prevention or mitigation of 403 future outbreaks (Bonilla-Aldana et al., 2020a). 
404

\section{6.2. Medical concerns}

406 - Initial reports of some pathologies such as rheumatic diseases or neuromyelitis optica

407 spectrum disorder (NMOSD) have shown that they do not increase the risk of complications

408 like other comorbidities. However, further studies are needed (Carnero Contentti \& Correa,

409 2020; Figueroa-Parra et al., 2020).

410 - Angiotensin II receptor blockers (ATII-RB) are hypertensive drugs that increase ACE2

411 expression; therefore, there is a possibility that they can favor the internalization of SARS-

412 CoV-2 within the cell; thus, further studies are required. However, suspending ATII-RB

413 therapy may cause even higher affectations than COVID-19 itself; the risk-benefit ratio

414 should be evaluated. In case doctors consider suspending it, there are other options like

415 thiazide diuretics drugs (Gracia-Ramos, 2020; Marin, 2020).

416 - As previously mentioned, chloroquine and hydroxychloroquine are in vitro inhibitors of

417 SARS-CoV-2 infection. However, concerns are focused on whether these medications could

418 decrease viral load or prevent infection, clinical disease, clinical severity, or even death.

419 Other factors, such as side effects, should also be considered (Kim et al., 2020; Monteiro et

420 al., 2020; Picot et al., 2020).

421 - COVID-19 mainly affects the respiratory system, but it can also alter the central nervous

422 system. Hence, possible affectations in the respiratory center could exacerbate respiratory

423 distress caused by pulmonary affectation (Conde et al., 2020).

424 - Tropical countries affected by dengue could face two outbreaks at the same time, dengue and

425 COVID-19, which could affect the population, even coinfecting some patients

426 simultaneously. Both outbreaks will require the intensive attention of health systems to avoid 
427 a crossed affectation between them, which can be challenging and overwhelming for the

428 health systems (Lorenz et al., 2020; Navarro et al., 2020; Rodriguez-Morales et al., 2020c;

429 Saavedra-Velasco et al., 2020).

430 - As SARS-CoV-2 can remain in saliva, oral health professionals require research focused on

431 the influence of COVID-19 in their activities to take appropriate measures. However, the

432 recommendation is to stop dental treatments (Martelli-Júnior et al., 2020; Napimoga \&

433 Freitas, 2020; Sabino-Silva et al., 2020).

434 - Strategies during intubation are not the only important ones to avoid COVID-19 spreading in

435 health workers during medical procedures; strategies for extubation are also required

$436 \quad$ (Trujillo, 2020).

437 - There is no evidence that immunosuppressant treatments (ITS) could decrease or increase the

438 risk of severe COVID-19 infection; therefore, further investigation is recommended. In case

439 treatments are suspended, factors such as potential issues on patients should be considered

440 (Carnero Contentti \& Correa, 2020).

441 - There is limited evidence of COVID-19 effect on pregnant women; hence, cases of pregnant

442 women with COVID-19 should be studied to understand the clinical impact of the infection

443 (Zambrano et al., 2020).

444

\section{Conclusions}

446 Although our purpose was to give visibility to the contribution of Latin American researchers in

447 the knowledge generation related to the COVID-19 outbreak, this review has two drawbacks.

448 The first is the continuous availability of new publications; therefore, an observation window

449 was employed. Second, several Latin American researchers are currently working on other 
450 continents without a Latin American affiliation, making them impossible to track. However, after

451 this literature review, we were able to evidence the active participation of Latin American

452 researchers in different subjects, whether as members of national, regional (LANCOVID-19), or

453 even international research groups. Concerning our findings, the publications evidenced that

454 these research groups have advanced in molecular and medical subjects, mainly in genetic

455 understanding, epidemiological behaviors, meta-analyses, interaction between COVID-19 and

456 other pathologies, and recommendations to medical procedures. Finally, understanding that this

457 health crisis requires the commitment of as many researchers as possible, our wish is that the

458 contribution of Latin American researchers continues to grow. Some topics with regional and

459 global interest for future studies include in silico analyses of potential treatments and their

460 respective in vitro and in vivo validations, meta-analysis of Latin American patients, and

461 epidemiological surveillances. Regarding medical considerations, a deeper understanding of the

462 COVID-19 interaction with risk comorbidities is needed to propose adequate clinical treatments.

463 The same applies to unexplored/underexplored physical and mental pathologies, such as dengue.

464

465 Acknowledgments

466 This review is in memory of all deceased by the COVID-19 outbreak.

\section{References}

469 Amariles P, Granados J, Ceballos M, and Montoya CJ. 2020a. COVID-19 in Colombia endpoints. Are we different, like Europe? Research in Social and Administrative Pharmacy. DOI 10.1016/j.sapharm.2020.03.013. 
472 Amariles P, Ledezma-Morales M, Salazar-Ospina A, and Hincapié-García JA. 2020b. How to

473 link patients with suspicious COVID-19 to health system from the community

474 pharmacies? A route proposal. Research in Social and Administrative Pharmacy. DOI

$475 \quad$ 10.1016/j.sapharm.2020.03.007.

476 Andersen KG, Rambaut A, Lipkin WI, Holmes EC, and Garry RF. 2020. The proximal origin of

477 SARS-CoV-2. Nature Medicine. DOI 10.1038/s41591-020-0820-9.

478 Angeletti S, Benvenuto D, Bianchi M, Giovanetti M, Pascarella S, and Ciccozzi M. 2020.

479 COVID-2019: The role of the nsp2 and nsp3 in its pathogenesis. Journal of Medical

$480 \quad$ Virology. DOI 10.1002/jmv.25719.

481 Aruru M, Truong H-A, and Clark S. 2020. Pharmacy Emergency Preparedness and Response

482 (PEPR) framework for expanding pharmacy professionals' roles and contributions to

483 emergency preparedness and response during the COVID-19 pandemic and beyond.

484 Research in Social and Administrative Pharmacy. DOI 10.1016/j.sapharm.2020.04.002.

485 Assis Machado R, Lins de Souza N, Maria Oliveira R, Martelli Júnior H, and Rogério Ferreti

486 Bonan P. 2020. Social Media and telemedicine for oral diagnosis and counselling in the

487 COVID-19 Era. Oral Oncology:104685. DOI 10.1016/j.oraloncology.2020.104685.

488 Bartlett RH, Ogino MT, Brodie D, McMullan DM, Lorusso R, MacLaren G, Stead CM, Rycus P,

489 Fraser JF, Belohlavek J, Salazar L, Mehta Y, Raman L, and Paden ML. 2020. Initial

490 ELSO Guidance Document: ECMO for COVID-19 Patients with Severe

491 Cardiopulmonary Failure. ASAIO Journal: Artificial Organ Research and Development

$492 \quad$ Online First. DOI 10.1097/mat.0000000000001173.

493 Benvenuto D, Angeletti S, Giovanetti M, Bianchi M, Pascarella S, Cauda R, Ciccozzi M, and

494 Cassone A. 2020a. Evolutionary analysis of SARS-CoV-2: how mutation of Non- 
495

496

497

498

499

500

501

502

503

504

505

506

507

508

509

510

511

512

513

514 Bonilla-Aldana DK, Quintero-Rada K, Montoya-Posada JP, Ramirez-Ocampo S, Paniz-Mondolfi

515

516

Structural Protein 6 (NSP6) could affect viral autophagy. Journal of Infection. DOI 10.1016/j.jinf.2020.03.058.

Benvenuto D, Giovanetti M, Ciccozzi A, Spoto S, Angeletti S, and Ciccozzi M. 2020b. The 2019-new coronavirus epidemic: Evidence for virus evolution. Journal of Medical Virology 92:455-459. DOI 10.1002/jmv.25688.

Benvenuto D, Giovanetti M, Salemi M, Prosperi M, De Flora C, Alcantara LC, Angeletti S, and Ciccozzi M. 2020c. The global spread of 2019-nCoV: a molecular evolutionary analysis. Pathogens and Global Health. DOI 10.1080/20477724.2020.1725339.

Benvenuto D, Giovanetti M, Vassallo L, Angeletti S, and Ciccozzi M. 2020d. Application of the ARIMA model on the COVID-2019 epidemic dataset. Data in Brief 29. DOI 10.1016/j.dib.2020.105340.

Boccalatte LA, Larrañaga JJ, Perez Raffo GM, Teijido CA, García Fornari G, Staneloni MI, and Figari MF. 2020. Brief guideline for the prevention of COVID-19 infection in head and neck and otolaryngology surgeons. American Journal of Otolaryngology:102484. DOI 10.1016/j.amjoto.2020.102484.

Bonilla-Aldana DK, Dhama K, and Rodriguez-Morales AJ. 2020a. Revisiting the One Health Approach in the Context of COVID-19: A Look into the Ecology of this Emerging Disease. Advances in Animal and Veterinary Sciences 8:234-236. DOI 10.17582/journal.aavs/2020/8.3.234.236.

A, Rabaan AA, Sah R, and Rodriguez-Morales AJ. 2020b. SARS-CoV, MERS-CoV and now the 2019-novel CoV: Have we investigated enough about coronaviruses? - A 
519 Borges do Nascimento JI, Cacic N, Abdulazeem MH, von Groote CT, Jayarajah U, Weerasekara Zakarija-Grkovic I, Meirelles Guimarães MS, Luigi Bragazzi N, Bjorklund M, SofiMahmudi A, Altujjar M, Tian M, Arcani MD, O’Mathúna PD, and Marcolino SM. 2020. Novel Coronavirus Infection (COVID-19) in Humans: A Scoping Review and MetaAnalysis. Journal of Clinical Medicine 9. DOI 10.3390/jcm9040941.

525

526

527 528 529 530 531 532 533 534 535 536 537 538 539

Candido DDS, Watts A, Abade L, Kraemer MUG, Pybus OG, Croda J, Oliveira W, Khan K, Sabino EC, and Faria NR. 2020. Routes for COVID-19 importation in Brazil. Journal of travel medicine. DOI 10.1093/jtm/taaa042.

Cardenas-Conejo Y, Linan-Rico A, Garcia-Rodriguez DA, Centeno-Leija S, and Serrano-Posada H. 2020. An exclusive 42 amino acid signature in pplab protein provides insights into the evolutive history of the 2019 novel human-pathogenic coronavirus (SARS-CoV-2). Journal of Medical Virology. DOI 10.1002/jmv.25758.

Carneiro A, Wroclawski M, Nahar B, Soares A, Cardoso A, Kim N, and Carvalho F. 2020. Impact of the COVID-19 Pandemic on the Urologist's clinical practice in Brazil: a management guideline proposal for low- and middle-income countries during the crisis period. International Brazilian Journal of Urology 46. DOI 10.1590/S16775538.IBJU.2020.04.03.

Carnero Contentti E, and Correa J. 2020. Immunosuppression during the COVID-19 pandemic in neuromyelitis optica spectrum disorders patients: A new challenge. Multiple Sclerosis and Related Disorders 41:102097. DOI 10.1016/j.msard.2020.102097. 
540 Carvalho LdF, Pianowski G, and Gonçalves AP. 2020a. Personality differences and COVID-19:

541

542

543

544

545

546

547

548

549

550

551

552

553

554

555

556

557

558

559

560 are extroversion and conscientiousness personality traits associated with engagement with containment measures? Trends in Psychiatry and Psychotherapy. DOI 10.1590/2237-6089-2020-0029.

Carvalho PMdM, Moreira MM, de Oliveira MNA, Landim JMM, and Neto MLR. 2020b. The psychiatric impact of the novel coronavirus outbreak. Psychiatry Research 286:112902. DOI 10.1016/j.psychres.2020.112902.

Castillo AE, Parra B, Tapia P, Acevedo A, Lagos J, Andrade W, Arata L, Leal G, Barra G, Tambley C, Tognarelli J, Bustos P, Ulloa S, Fasce R, and Fernández J. 2020. Phylogenetic analysis of the first four SARS-CoV-2 cases in Chile. Journal of Medical Virology n/a. DOI 10.1002/jmv.25797.

Ciccozzi M, Benvenuto D, Giovanetti M, Bianchi M, Pascarella S, and Angeletti S. 2020.

Response to Ribeiro da Silva et al.,"Role of Nonstructural Proteins in the Pathogenesis of SARS-CoV-2. Journal of Medical Virology n/a. DOI 10.1002/jmv.25863.

Ciotti M, Angeletti S, Minieri M, Giovannetti M, Benvenuto D, Pascarella S, Sagnelli C, Bianchi M, Bernardini S, and Ciccozzi M. 2020. COVID-19 Outbreak: An Overview. Chemotherapy. DOI 10.1159/000507423.

Cleemput S, Dumon W, Fonseca V, Karim WA, Giovanetti M, Alcantara LC, Deforche K, and de Oliveira T. 2020. Genome Detective Coronavirus Typing Tool for rapid identification and characterization of novel coronavirus genomes. Bioinformatics. DOI 10.1093/bioinformatics/btaa145. 
561 Cohen SL, Liu G, Abrao M, Smart N, and Heniford T. 2020. Perspectives on Surgery in the time 562 of COVID-19: Safety First. Journal of Minimally Invasive Gynecology. DOI $563 \quad$ 10.1016/j.jmig.2020.04.003.

564 Conde G, Quintana Pájaro LD, Quintero Marzola ID, Villegas YR, and Moscote Salazar LR. 565 2020. Neurotropism of SARS-CoV 2: Mechanisms and manifestations. Journal of the Neurological Sciences:116824. DOI 10.1016/j.jns.2020.116824.

567 Córdova-Lepe F, Gutiérrez-Aguilar R, and Gutiérrez-Jara JP. 2020. Number of COVID-19 cases 568 in Chile at 120 days with data at 21/03/2020 and threshold of daily effort to flatten the epi-curve. Medwave 20:e7861. DOI 10.5867/medwave.2020.02.7861.

570

571

572

573

574

575

576

577

578

579

580

581 Revista do Colégio Brasileiro de Cirurgiões 47. DOI 10.1590/0100-6991e-20202536.

Correia MITD, Ramos RF, and Bahten LCV. 2020. Os cirurgiões e a pandemia do COVID-19.

Cuan-Baltazar JY, Muñoz-Perez MJ, Robledo-Vega C, Pérez-Zepeda MF, and Soto-Vega E. 2020. Misinformation of COVID-19 on the Internet: Infodemiology Study. JMIR Public Health Surveill 6:e18444. DOI 10.2196/18444.

Cupertino MC, Resende MB, Mayers NAJ, Carvalho LM, and Siqueira-Batista R. 2020. Emerging and re-emerging human infectious diseases: A systematic review of the role of wild animals with a focus on public health impact. Asian Pacific Journal of Tropical Medicine 13:99-106. DOI 10.4103/1995-7645.277535.

Chica-Meza C, Peña-López LA, Villamarín-Guerrero HF, Moreno-Collazos JE, RodríguezCorredor LC, Lozano WM, and Vargas-Ordoñez MP. 2020. Cuidado Respiratorio En Covid-19. Acta Colombiana de Cuidado Intensivo. DOI 10.1016/j.acci.2020.04.001. 
582 de Figueiredo AM, Codina AD, de Figueiredo DCMM, Gil-García E, and Kalache A. 2020.

583 Letalidad del COVID-19: ausencia de patrón epidemiológico. Gaceta Sanitaria. DOI $584 \quad 10.1016 /$ j.gaceta.2020.04.001.

585 Diaz-Quijano FA, Rodriguez-Morales AJ, and Waldman EA. 2020. Translating transmissibility 586 measures into recommendations for coronavirus prevention. Revista de Saúde Pública 54. DOI 10.11606/s1518-8787.2020054002471.

Ducournau F, Arianni M, Awwad S, Baur EM, Beaulieu JY, Bouloudhnine M, Caloia M, Chagar K, Chen Z, Chin AY, Chow EC, Cobb T, David Y, Delgado PJ, Woon Man Fok M, French R, Golubev I, Haugstvedt JR, Ichihara E, Jorquera RA, Koo SCJJ, Lee JY, Lee YK, Lee YJ, Liu B, Kaleli T, Mantovani GR, Mathoulin C, Messina JC, Muccioli C, Nazerani S, Ng CY, Obdeijn MC, Van Overstraeten L, Prasetyono TOH, Ross M, Shih JT, Smith N, Suarez RFA, Chan PT, Tiemdjo H, Wahegaonkar A, Wells MC, Wong WY, Wu F, Yang XF, Yanni D, Yao J, and Liverneaux PA. 2020. COVID-19: Initial experience of an international group of hand surgeons. Hand Surgery and Rehabilitation. DOI 10.1016/j.hansur.2020.04.001.

Elachola H, Ebrahim SH, and Gozzer E. 2020. COVID-19: Facemask use prevalence in international airports in Asia, Europe and the Americas, March 2020. Travel Medicine and Infectious Disease:101637. DOI 10.1016/j.tmaid.2020.101637.

Escalera-Antezana JP, Lizon-Ferrufino NF, Maldonado-Alanoca A, Alarcón-De-la-Vega G, Alvarado-Arnez LE, Balderrama-Saavedra MA, Bonilla-Aldana DK, and RodríguezMorales AJ. 2020. Clinical features of cases and a cluster of Coronavirus Disease 2019 (COVID-19) in Bolivia imported from Italy and Spain. Travel Medicine and Infectious Disease:101653. DOI 10.1016/j.tmaid.2020.101653. 
605 Figueroa-Parra G, Aguirre-Garcia GM, Gamboa-Alonso CM, Camacho-Ortiz A, and Galarza606 Delgado DA. 2020. Are my patients with rheumatic diseases at higher risk of COVID607 19? Annals of the Rheumatic Diseases. DOI 10.1136/annrheumdis-2020-217322.

608 Fonseca L, Diniz E, Mendonça G, Malinowski F, Mari J, and Gadelha A. 2020. Schizophrenia 609 and COVID-19: risks and recommendations. Brazilian Journal of Psychiatry. DOI

610 10.1590/1516-4446-2020-0010.

611 Giovanetti M, Angeletti S, Benvenuto D, and Ciccozzi M. 2020a. A doubt of multiple 612 introduction of SARS-CoV-2 in Italy: A preliminary overview. Journal of Medical

613 Virology. DOI 10.1002/jmv.25773.

614 Giovanetti M, Benvenuto D, Angeletti S, and Ciccozzi M. 2020b. The first two cases of 2019615 nCoV in Italy: Where they come from? Journal of Medical Virology 92:518-521. DOI

616 10.1002/jmv.25699.

617 González-Jaramillo V, González-Jaramillo N, Gómez-Restrepo C, Palacio-Acosta CA, Gómez618 López A, and Franco OH. 2020. Proyecciones de impacto de la pandemia COVID-19 en 619 la población colombiana, según medidas de mitigación. Datos preliminares de modelos 620 epidemiológicos para el periodo del 18 de marzo al 18 de abril de 2020. Revista de Salud Pública 22. DOI 10.15446/rsap.v22.85789.

622 Gracia-Ramos AE. 2020. Is the ACE2 Overexpression a Risk Factor for COVID-19 Infection? 623 Archives of Medical Research. DOI 10.1016/j.arcmed.2020.03.011.

624 Hadfield J, Megill C, Bell SM, Huddleston J, Potter B, Callender C, Sagulenko P, Bedford T, 625 and Neher RA. 2018. NextStrain: Real-time tracking of pathogen evolution.

626 Bioinformatics 34:4121-4123. DOI 10.1093/bioinformatics/bty407. 
627 Haines A, de Barros EF, Berlin A, Heymann DL, and Harris MJ. 2020. National UK programme 628 of community health workers for COVID-19 response. The Lancet 395:1173-1175. DOI

629

630

631

632

633

634

635

636

637

638

639

640

641

642

643

644

645

646

647

648 10.1016/S0140-6736(20)30735-2.

Hallo A, Rojas A, and Hallo C. 2020. Perspective from Ecuador, the Second Country with More Confirmed Cases of Coronavirus Disease 2019 in South America: A Review. Cureus 12. DOI 10.7759/cureus.7452.

Hrusak O, Kalina T, Wolf J, Balduzzi A, Provenzi M, Rizzari C, Rives S, del Pozo Carlavilla M, Valerio Alonso ME, Domínguez Pinilla N, Bourquin J-P, Schmiegelow K, Attarbaschi A, Grillner P, Mellgren K, Ten Bosch van der Werff J, Pieters R, Brozou T, Borkhardt A, Escherich G, Lauten M, Stanulla M, Smith O, Juh Yeoh AE, Elitzur S, Vora A, Li C-K, Ariffin H, Kolenova A, Dallapozza L, Farah R, Lazic J, Manabe A, Styczynski J, Kovacs G, Ottoffy G, Felice M, Buldini B, Conter V, Stary J, and Schrappe M. 2020. Flash Survey on SARS-CoV-2 Infections in Pediatric Patients on anti-Cancer Treatment. European Journal of Cancer. DOI 10.1016/j.ejca.2020.03.021.

Huang C, Wang Y, Li X, Ren L, Zhao J, Hu Y, Zhang L, Fan G, Xu J, Gu X, Cheng Z, Yu T, Xia J, Wei Y, Wu W, Xie X, Yin W, Li H, Liu M, Xiao Y, Gao H, Guo L, Xie J, Wang G, Jiang R, Gao Z, Jin Q, Wang J, and Cao B. 2020. Clinical features of patients infected with 2019 novel coronavirus in Wuhan, China. The Lancet 395:497-506. DOI 10.1016/s0140-6736(20)30183-5.

Hussain A, Bhowmik B, and do Vale Moreira NC. 2020. COVID-19 and Diabetes: Knowledge in Progress. Diabetes Research and Clinical Practice:108142. DOI 10.1016/j.diabres.2020.108142. 
649 Johns Hopkins University. 2020. COVID-19 Dashboard by the Center for Systems Science and 650 Engineering (CSSE). Available at https://coronavirus.jhu.edu/map.html.

651 Khoury M, Cuenca J, Cruz FF, Figueroa FE, Rocco PRM, and Weiss DJ. 2020. Current Status of 652 Cell-Based Therapies for Respiratory Virus Infections: Applicability to COVID-19. 653 European Respiratory Journal:2000858. DOI 10.1183/13993003.00858-2020.

654 Kim AHJ, Sparks JA, Liew JW, Putman MS, Berenbaum F, Duarte-García A, Graef ER, Korsten 655 P, Sattui SE, Sirotich E, Ugarte-Gil MF, Webb K, Grainger R, and Alliance $\uparrow$ C-GR. 2020. A Rush to Judgment? Rapid Reporting and Dissemination of Results and Its Consequences Regarding the Use of Hydroxychloroquine for COVID-19. Annals of internal medicine:M20-1223. DOI 10.7326/m20-1223.

Kowalski LP, Sanabria A, Ridge JA, Ng WT, de Bree R, Rinaldo A, Takes RP, Mäkitie AA, Carvalho AL, Bradford CR, Paleri V, Hartl DM, Poorten VV, Nixon IJ, Piazza C, Lacy P, Rodrigo JP, Guntinas-Lichius O, Mendenhall WM, D'Cruz A, Lee AWM, and Ferlito A. 2020. COVID-19 pandemic: effects and evidence-based recommendations for otolaryngology and head and neck surgery practice. Head \& Neck n/a. DOI 10.1002/hed.26164.

Kraemer MUG, Yang C-H, Gutierrez B, Wu C-H, Klein B, Pigott DM, du Plessis L, Faria NR, Li R, Hanage WP, Brownstein JS, Layan M, Vespignani A, Tian H, Dye C, Pybus OG, and Scarpino SV. 2020. The effect of human mobility and control measures on the COVID-19 epidemic in China. Science:eabb4218. DOI 10.1126/science.abb4218.

Lagunas-Rangel FA. 2020. Neutrophil-to-Lymphocyte ratio and Lymphocyte-to-C-reactive protein ratio in patients with severe coronavirus disease 2019 (COVID-19): A metaanalysis. Journal of Medical Virology n/a. DOI 10.1002/jmv.25819. 
672 Lana RM, Coelho FC, Gomes MFDC, Cruz OG, Bastos LS, Villela DAM, and Codeço CT.

673 2020. The novel coronavirus (SARS-CoV-2) emergency and the role of timely and

674 effective national health surveillance. Cadernos de saude publica 36:e00019620. DOI

$675 \quad 10.1590 / 0102-311 \times 00019620$.

676 Leng Z, Zhu R, Hou W, Feng Y, Yang Y, Han Q, Shan G, Meng F, Du D, Wang S, Fan J, Wang

677 W, Deng L, Shi H, Li H, Hu Z, Zhang F, Gao J, Liu H, Li X, Zhao Y, Yin K, He X, Gao

678 Z, Wang Y, Yang B, Jin R, Stambler I, Lim LW, Su H, Moskalev A, Cano A,

679 Chakrabarti S, Min K-J, Ellison-Hughes G, Caruso C, Jin K, and Zhao RC. 2020.

680 Transplantation of ACE2(-) Mesenchymal Stem Cells Improves the Outcome of Patients

$681 \quad$ with COVID-19 Pneumonia. Aging and Disease 11:216-228. DOI

$682 \quad 10.14336 /$ ad.2020.0228.

683 Lima CKT, Carvalho PMDM, Lima IDAAS, Nunes JVADO, Saraiva JS, de Souza RI, da Silva

684 CGL, and Neto MLR. 2020. The emotional impact of Coronavirus 2019-nCoV (new

685 Coronavirus disease). Psychiatry Research 287. DOI 10.1016/j.psychres.2020.112915.

686 Lorenz C, Azevedo TS, and Chiaravalloti-Neto F. 2020. COVID-19 and dengue fever: A

687 dangerous combination for the health system in Brazil. Travel Medicine and Infectious

688 Disease:101659. DOI 10.1016/j.tmaid.2020.101659.

689 Manrique-Abril FG, Agudelo-Calderon CA, González-Chordá VM, Gutiérrez-Lesmes O, Téllez-

690 Piñerez CF, and Herrera-Amaya G. 2020. Modelo SIR de la pandemia de COVID-19 en

691 Colombia. Revista de Salud Pública 22. DOI 10.15446/rsap.v22.85977.

692 Marin GH. 2020. Facts and reflections on COVID-19 and anti-hypertensives drugs. Drug

693 Discoveries \& Therapeutics. DOI 10.5582/ddt.2020.01017. 
694 Martelli-Júnior H, Machado RA, Martelli DRB, and Coletta RD. 2020. Dental journals and 695 coronavirus disease (COVID-19): A current view. Oral Oncology:104664. DOI $696 \quad 10.1016 /$ j.oraloncology.2020.104664.

697 Martins PR, and Santos VS. 2020. No evidence supports the use of ether and chloroform 698 inhalation for treating COVID-19. Revista Panamericana De Salud Publica-Pan American Journal of Public Health 44. DOI 10.26633/rpsp.2020.41.

700

701

702

703

704 705

706

707

708

709

710

711

712

713

714

715

Millán-Oñate J, Rodriguez-Morales AJ, Camacho-Moreno G, Mendoza-Ramírez H, RodríguezSabogal IA, and Álvarez-Moreno C. 2020. A NEW EMERGING ZOONOTIC VIRUS OF CONCERN: THE 2019 NOVEL CORONAVIRUS (COVID-19). Infectio 24. DOI 10.22354/in.v24i3.848.

Monteiro WM, Brito-Sousa JD, Baía-da-Silva D, Melo GCd, Siqueira AM, Val F, DanielRibeiro CT, and Guimarães Lacerda MV. 2020. Driving forces for COVID-19 clinical trials using chloroquine: the need to choose the right research questions and outcomes. Revista da Sociedade Brasileira de Medicina Tropical 53. DOI 10.1590/0037-86820155-2020.

Napimoga MH, and Freitas ARRd. 2020. Dentistry vs Severe Acute Respiratory Syndrome Coronavirus 2: How to face this enemy. RGO - Revista Gaúcha de Odontologia 68. DOI $10.1590 / 1981-863720200001120200034$

Navarro J-C, Arrivillaga-Henríquez J, Salazar-Loor J, and Rodriguez-Morales AJ. 2020. COVID-19 and dengue, co-epidemics in Ecuador and other countries in Latin America: Pushing strained health care systems over the edge. Travel Medicine and Infectious Disease:101656. DOI 10.1016/j.tmaid.2020.101656. 
716 Namendys-Silva SA. 2020a. ECMO for ARDS due to COVID-19. Heart \& Lung. DOI

$717 \quad$ 10.1016/j.hrtlng.2020.03.012.

718 Namendys-Silva SA. 2020b. Respiratory support for patients with COVID-19 infection. The

719 Lancet Respiratory Medicine 8:e18. DOI 10.1016/s2213-2600(20)30110-7.

720 Oliveira TC, Abranches MV, and Lana RM. 2020. (In)Segurança alimentar no contexto da

$721 \quad$ pandemia por SARS-CoV-2. Cadernos de saude publica 36. DOI 10.1590/0102-

$722 \quad 311 X 00055220$.

723 Ornell F, Schuch JB, Sordi AO, and Kessler FHP. 2020. "Pandemic fear" and COVID-19:

724 mental health burden and strategies. Brazilian Journal of Psychiatry. DOI 10.1590/1516-

$725 \quad 4446-2020-0008$.

726 Ortega JT, Serrano ML, Pujol FH, and Rangel HR. 2020a. Role of changes in SARS-CoV-2

727 spike protein in the interaction with the human ACE2 receptor: An in silico analysis.

728 EXCLI journal 19:410-417. DOI 10.17179/excli2020-1167.

729 Ortega JT, Serrano ML, Pujol FH, and Rangel HR. 2020b. Unrevealing sequence and structural

730 features of novel coronavirus using in silico approaches: The main protease as molecular

$731 \quad$ target. EXCLI journal 19:400-409. DOI 10.17179/excli2020-1189.

732 Palacios Cruz M, Santos E, Velázquez Cervantes MA, and León Juárez M. 2020. COVID-19,

733 una emergencia de salud pública mundial. Revista Clínica Española. DOI

$734 \quad$ 10.1016/j.rce.2020.03.001.

735 Picot S, Marty A, Bienvenu A-L, Blumberg LH, Dupouy-Camet J, Carnevale P, Kano S, Jones

736 MK, Daniel-Ribeiro CT, and Mas-Coma S. 2020. Coalition: Advocacy for prospective

737 clinical trials to test the post-exposure potential of hydroxychloroquine against COVID-

738 19. One Health:100131. DOI 10.1016/j.onehlt.2020.100131. 
739 Puliatti S, Eissa A, Eissa R, Amato M, Mazzone E, Dell’Oglio P, Sighinolfi MC, Zoeir A, Micali

740 S, Bianchi G, Patel V, Wiklund P, Coelho RF, Bernhard J-C, Dasgupta P, Mottrie A, and

741

742

743

744

745

746

747

748

749

750

751

752

753

754

755

756

757

758

759

760

761 Rocco B. 2020. COVID-19 and Urology: A Comprehensive Review of the Literature. BJU International n/a. DOI 10.1111/bju.15071.

Quintão VC, Simões CM, Lima LHNe, Barros GAMd, Salgado-Filho MF, Guimarães GMN, Alves RL, Caetano AMM, Schmidt AP, and Carmona MJC. 2020. The Anesthesiologist and COVID-19. Brazilian Journal of Anesthesiology (English Edition). DOI 10.1016/j.bjane.2020.03.002.

Rascado Sedes P, Ballesteros Sanz MÁ, Bodí Saera MA, Carrasco Rodríguez-Rey LF, Castellanos Ortega Á, Catalán González M, de Haro López C, Díaz Santos E, Escriba Barcena A, Frade Mera MJ, Igeño Cano JC, Martín Delgado MC, Martínez Estalella G, Raimondi N, Roca I Gas O, Rodríguez Oviedo A, Romero San Pío E, Trenado Álvarez J, and Raurell M. 2020. Plan de contingencia para los servicios de medicina intensiva frente a la pandemia COVID-19•. Enfermería Intensiva. DOI 10.1016/j.enfi.2020.03.001.

Rodriguez-Morales AJ, Bonilla-Aldana DK, Tiwari R, Sah R, Rabaan AA, and Dhama K. 2020a. COVID-19, an Emerging Coronavirus Infection: Current Scenario and Recent Developments - An Overview. Journal of Pure and Applied Microbiology 14:05-12. DOI 10.22207/JPAM.14.1.02.

Rodriguez-Morales AJ, Cardona-Ospina JA, Gutiérrez-Ocampo E, Villamizar-Peña R, HolguinRivera Y, Escalera-Antezana JP, Alvarado-Arnez LE, Bonilla-Aldana DK, FrancoParedes C, Henao-Martinez AF, Paniz-Mondolfi A, Lagos-Grisales GJ, Ramírez-Vallejo E, Suárez JA, Zambrano LI, Villamil-Gómez WE, Balbin-Ramon GJ, Rabaan AA, Harapan H, Dhama K, Nishiura H, Kataoka H, Ahmad T, Sah R, and Latin American 
762

763

764

765

766

767

768

769

770

771

772

773

774

775

776

777

778

779

780

781

782

783

Network of Coronavirus Disease C-R. 2020b. Clinical, laboratory and imaging features of COVID-19: A systematic review and meta-analysis. Travel Medicine and Infectious Disease. DOI 10.1016/j.tmaid.2020.101623.

Rodriguez-Morales AJ, Sah R, and Paniz-Mondolfi A. 2020c. Should the Holy Week 2020 be cancelled in Latin America due to the COVID-19 pandemic? Travel Medicine and Infectious Disease:101633. DOI 10.1016/j.tmaid.2020.101633.

Rodriguez-Morales AJ, Sánchez-Duque JA, Hernández Botero S, Pérez-Díaz CE, VillamilGómez WE, Méndez CA, Verbanaz S, Cimerman S, Rodriguez-Enciso HD, EscaleraAntezana JP, Balbin-Ramon GJ, Arteaga-Livias FK, Cvetkovic-Vega A, Orduna T, Savio-Larrea E, and Paniz-Mondolfi A. 2020d. Preparación y control de la enfermedad por coronavirus 2019 (COVID-19) en América Latina. ACTA MEDICA PERUANA 37. DOI 10.35663/amp.2020.371.909.

Rosa SGV, and Santos WC. 2020. Clinical trials on drug repositioning for COVID-19 treatment. Revista Panamericana De Salud Publica-Pan American Journal of Public Health 44. DOI 10.26633/rpsp.2020.40.

Rosales-Mendoza S. 2020. Will plant-made biopharmaceuticals play a role in the fight against COVID-19? Expert Opinion on Biological Therapy:null-null. DOI $10.1080 / 14712598.2020 .1752177$.

Saavedra-Velasco M, Chiara-Chilet C, Pichardo-Rodriguez R, Grandez-Urbina A, and IngaBerrospi F. 2020. Coinfección entre dengue y COVID-19: Necesidad de abordaje en zonas endémicas. Revista de la Facultad de Ciencias Médicas de Córdoba 77. DOI 10.31053/1853.0605.v77.n1.28031. 
784 Sabino-Silva R, Jardim ACG, and Siqueira WL. 2020. Coronavirus COVID-19 impacts to 785 dentistry and potential salivary diagnosis. Clinical Oral Investigations. DOI

786 10.1007/s00784-020-03248-x.

787

788

789

790

791

792

793

794

795

796

797

798

799

800

801

802

803

804

805

Sagulenko P, Puller V, and Neher RA. 2018. TreeTime: Maximum-likelihood phylodynamic analysis. Virus evolution 4:vex042-vex042. DOI 10.1093/ve/vex042.

Sah R, Rodriguez-Morales AJ, Jha R, Chu DKW, Gu H, Peiris M, Bastola A, Lal BK, Ojha HC, Rabaan AA, Zambrano LI, Costello A, Morita K, Pandey BD, and Poon LLM. 2020. Complete genome sequence of a 2019 novel coronavirus (SARS-COV-2) strain isolated in Nepal. Microbiology Resource Announcements 9. DOI 10.1128/mra.00169-20.

Sawano T, Ozaki A, Rodriguez-Morales AJ, Tanimoto T, and Sah R. 2020. Limiting spread of COVID-19 from cruise ships - lessons to be learnt from Japan. QJM: An International Journal of Medicine. DOI 10.1093/qjmed/hcaa092.

Serafin MB, Bottega A, Foletto VS, da Rosa TF, Hörner A, and Hörner R. 2020. Drug repositioning an alternative for the treatment of coronavirus COVID-19. International Journal of Antimicrobial Agents:105969. DOI 10.1016/j.ijantimicag.2020.105969.

Sifuentes-Rodriguez E, and Palacios-Reyes D. 2020. COVID-19: The outbreak caused by a new coronavirus. Boletin Medico Del Hospital Infantil De Mexico 77:47-53. DOI 10.24875/bmhim.20000039.

Siordia JA. 2020. Epidemiology and Clinical Features of COVID-19: A Review of Current Literature. Journal of Clinical Virology:104357. DOI 10.1016/j.jcv.2020.104357.

Stern D, López-Olmedo N, Pérez-Ferrer C, González-Morales R, Canto-Osorio F, and Barrientos-Gutiérrez T. 2020. Revisión rápida del uso de cubrebocas quirúrgicos en 

ámbito comunitario e infecciones respiratorias agudas. Salud Pública de México. DOI 807 $10.21149 / 11379$.

808 Torales J, Higgins M, Castaldelli-Maia JM, and Ventriglio A. 2020. The outbreak of COVID-19 809 coronavirus and its impact on global mental health. International Journal of Social 810 Psychiatry:20764020915212-20764020915212. DOI 10.1177/0020764020915212.

811 Torres I, and Sacoto F. 2020. Localising an asset-based COVID-19 response in Ecuador. The 812 Lancet. DOI 10.1016/S0140-6736(20)30851-5.

813 Trujillo A. 2020. Response to Wen and Li. Anesthesia Procedure of Emergency Operation for 814 Patients with Suspected or Confirmed COVID-19 (DOI: 10.1089/sur.2020.040). Surg 815 infect,(Larchmt). DOI 10.1089/sur.2020.088.

816 van Doremalen N, Bushmaker T, Morris DH, Holbrook MG, Gamble A, Williamson BN, Tamin 817 A, Harcourt JL, Thornburg NJ, Gerber SI, Lloyd-Smith JO, de Wit E, and Munster VJ. 818 2020. Aerosol and Surface Stability of SARS-CoV-2 as Compared with SARS-CoV-1. New England Journal of Medicine. DOI 10.1056/NEJMc2004973. 821

Vega-Vega O, Arvizu-Hernández M, Domínguez-Cherit JG, Sierra-Madero J, and Correa-Rotter R. 2020. Prevención y control de la infección por coronavirus SARS-CoV-2 (Covid-19) en unidades de hemodiálisis. Salud Pública de México. DOI 10.21149/11330.

Wu D, Wu T, Liu Q, and Yang Z. 2020. The SARS-CoV-2 outbreak: What we know. International Journal of Infectious Diseases 94:44-48. DOI 10.1016/j.ijid.2020.03.004.

Xu B, Gutierrez B, Mekaru S, Sewalk K, Goodwin L, Loskill A, Cohn EL, Hswen Y, Hill SC, 826 Cobo MM, Zarebski AE, Li S, Wu CH, Hulland E, Morgan JD, Wang L, O’Brien K, Scarpino SV, Brownstein JS, Pybus OG, Pigott DM, and Kraemer MUG. 2020. 
828 Epidemiological data from the COVID-19 outbreak, real-time case information. Scientific 829 Data 7. DOI 10.1038/s41597-020-0448-0.

830 Zambrano LI, Fuentes-Barahona IC, Bejarano-Torres DA, Bustillo C, Gonzales G, Vallecillo831 Chinchilla G, Sanchez-Martínez FE, Valle-Reconco JA, Sierra M, Bonilla-Aldana DK, 832 Cardona-Ospina JA, and Rodríguez-Morales AJ. 2020. A pregnant woman with COVID83319 in Central America. Travel Medicine and Infectious Disease:101639. DOI

834 10.1016/j.tmaid.2020.101639.

835 Zhu N, Zhang D, Wang W, Li X, Yang B, Song J, Zhao X, Huang B, Shi W, Lu R, Niu P, Zhan 836 F, Ma X, Wang D, Xu W, Wu G, Gao GF, and Tan W. 2020. A novel coronavirus from 837 patients with pneumonia in China, 2019. New England Journal of Medicine 382:727-733. 838 DOI 10.1056/NEJMoa2001017.

839

840 
Figure 1

PRISMA Flow diagram of selection process of COVID-19 or SAR-CoV-2 publications containing researchers with Latin American affiliation.

Identification stage was performed on April 10, 2020. 


\section{PRISMA 2009 Flow Diagram}

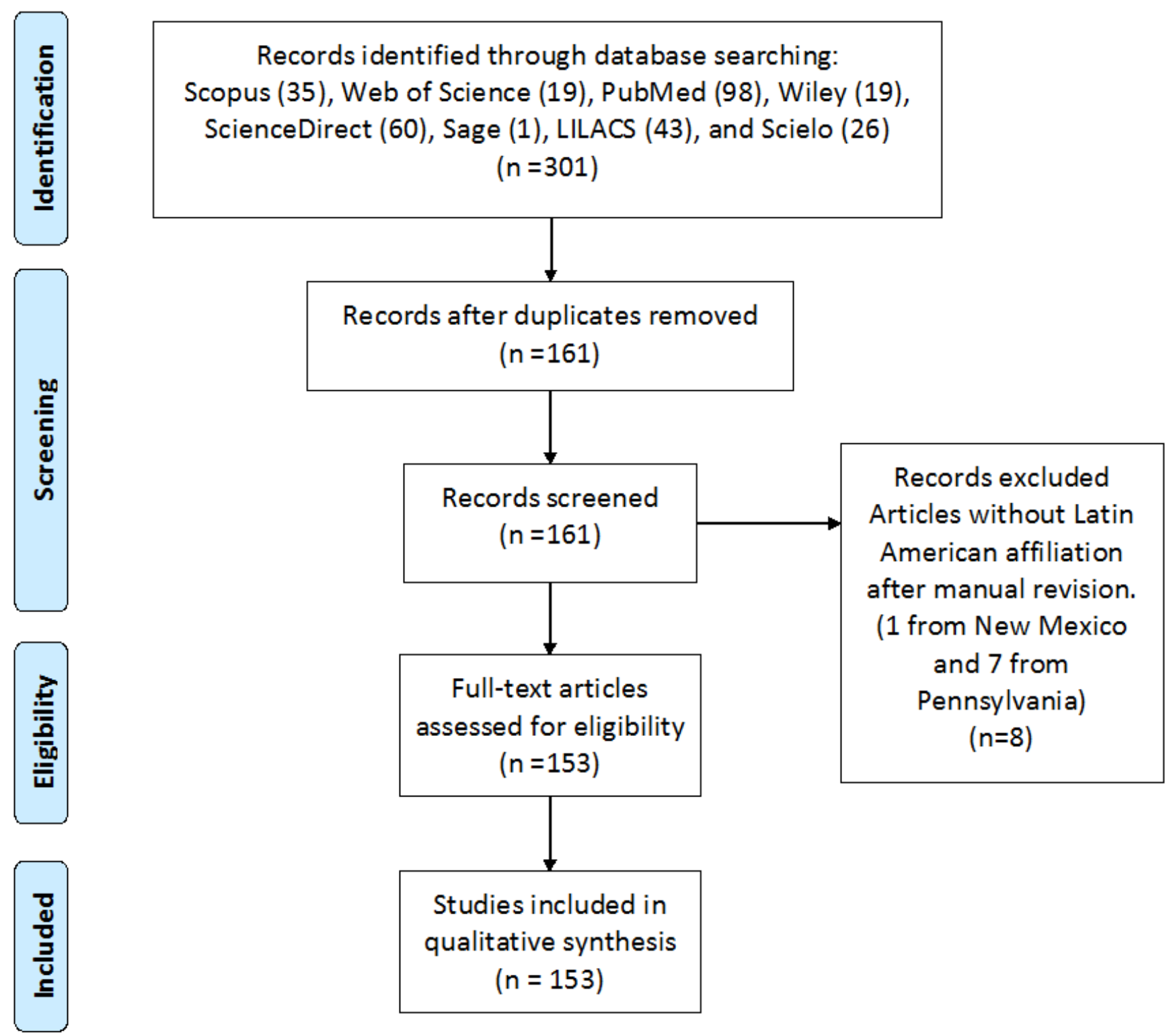


Figure 2

\section{Classification of publications by category}

Other publications refer to: Consensus statement, Contribution, and Technical note.

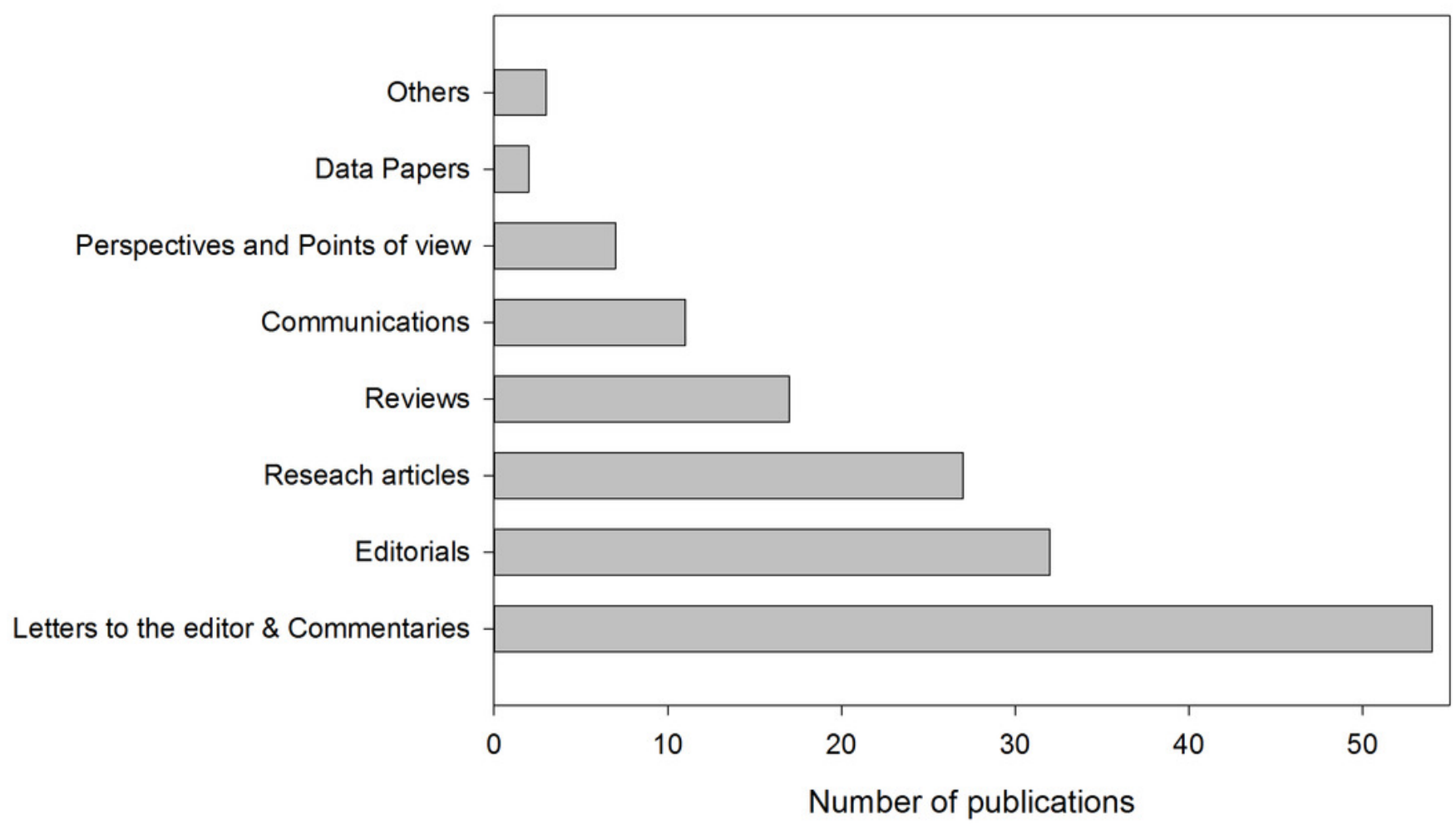


Figure 3

Classification of publications according to the national affiliation.

Several authors from the same country in a publication were counted as one contribution to the country. Publications with authors from different countries were counted as one for each country. Latin American countries not shown had no publications until April 10, 2020.

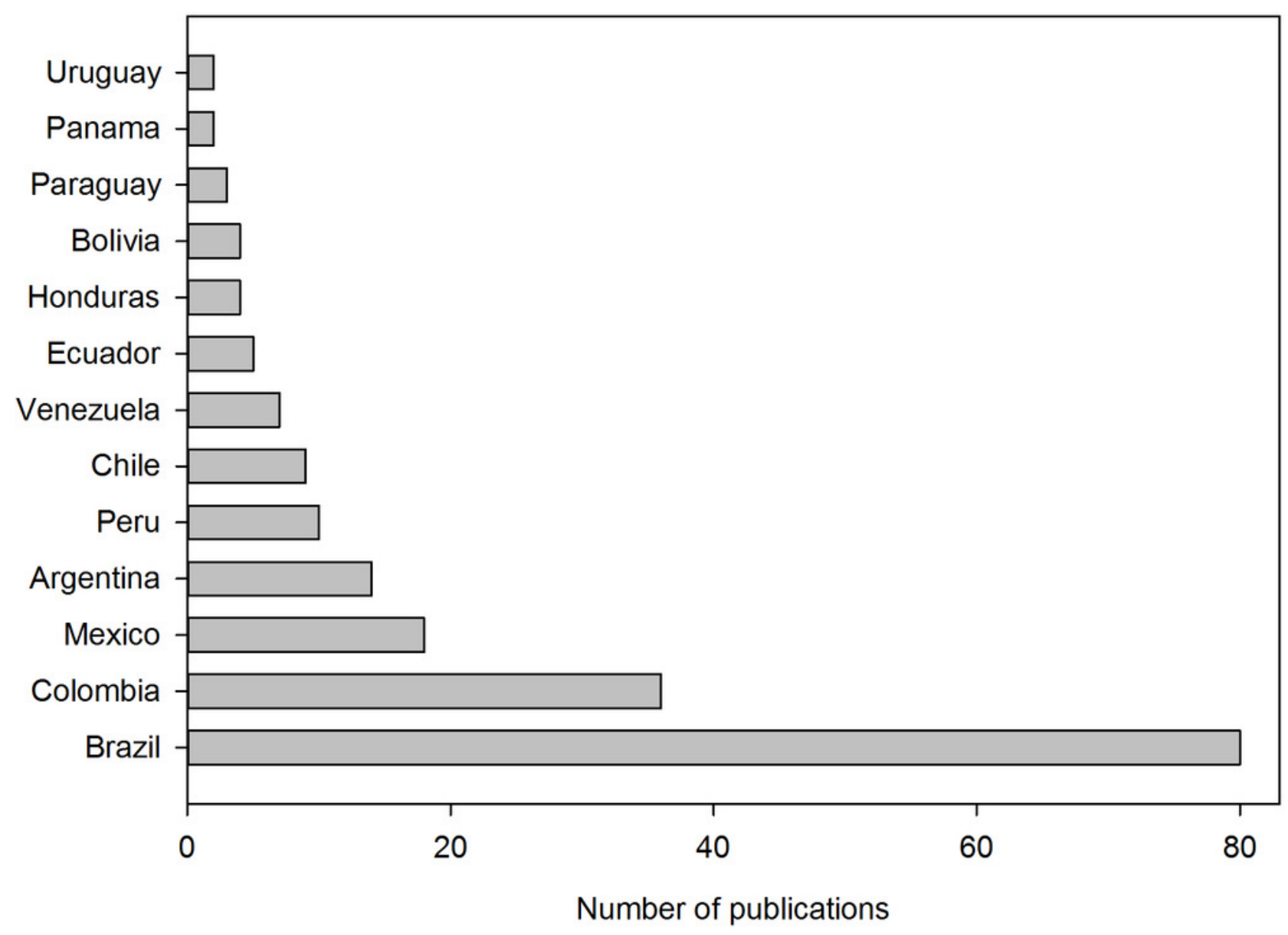




\section{Figure 4}

Classification of publications by topic.

Medical considerations refer to surgery recommendations, diagnosis, comorbidities, medical guidelines, dentistry considerations, among others. The general aspects include zoonotic links, spreading, origin, disease, surveillance, among others. Bioinformatics refers to molecular and phylogenetic analyses, molecular simulations, genetic annotations, among others.

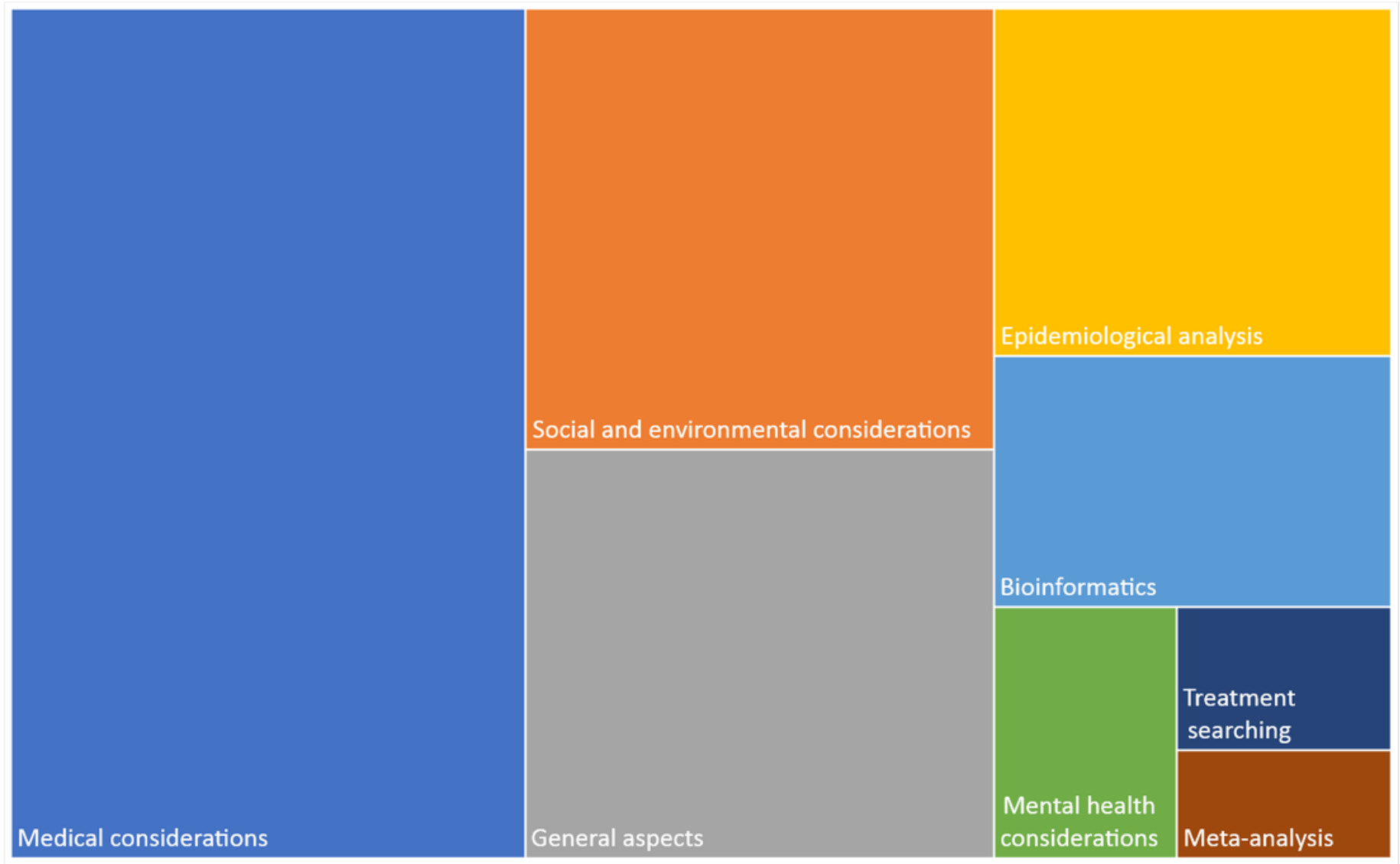


Figure 5

Phylogenetic location of genome sequences of some strains isolated in Latin America in the SARS-CoV-2 phylogenetic tree.

The phylogenetic tree was generated and adapted from the GISAID database (Hadfield et al., 2018; Sagulenko et al., 2018). The tree was retrieved on April 20, 2020.
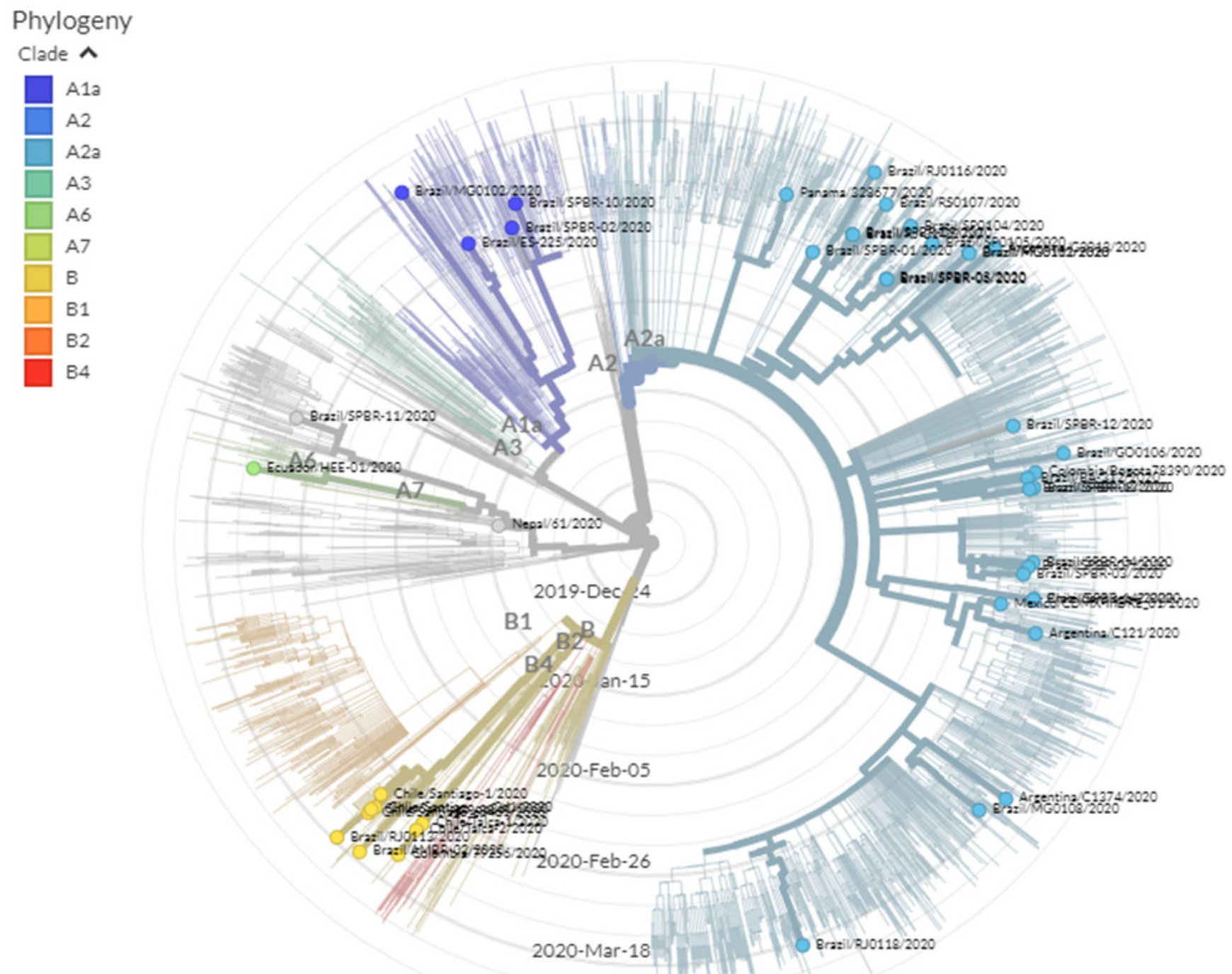


\section{Table 1 (on next page)}

Summary of the COVID-19 outbreak affectation in the Latin American countries.

Total cases and total deaths are reported until April 20, 2020 (Johns Hopkins University 2020). 


\begin{tabular}{|c|c|c|c|}
\hline \begin{tabular}{|l|} 
Country \\
\end{tabular} & First case & Cases & Deaths \\
\hline Argentina & Mar 3 & 2941 & 136 \\
\hline Bolivia & Mar 10 & 564 & 33 \\
\hline Brazil & Feb 25 & 40581 & 2845 \\
\hline Chile & Mar 3 & 10507 & 139 \\
\hline Colombia & Mar 6 & 3963 & 189 \\
\hline Costa Rica & Mar 6 & 662 & 6 \\
\hline Cuba & Mar 11 & 1087 & 36 \\
\hline Dominican Rep. & Mar 1 & 4964 & 235 \\
\hline Ecuador & Feb 14 & 10128 & 507 \\
\hline El Salvador & Mar 18 & 218 & 7 \\
\hline Guatemala & Mar 13 & 289 & 7 \\
\hline Haiti & Mar 2 & 47 & 3 \\
\hline Honduras & Mar 11 & 477 & 46 \\
\hline Mexico & Feb 27 & 8261 & 686 \\
\hline Nicaragua & Mar 18 & 10 & 2 \\
\hline Panama & Mar 8 & 4467 & 126 \\
\hline Paraguay & Mar 7 & 208 & 8 \\
\hline Peru & Mar 6 & 16325 & 445 \\
\hline Uruguay & Mar 13 & 528 & 10 \\
\hline Venezuela & Mar 13 & 256 & 9 \\
\hline \multicolumn{2}{|r|}{ Total } & 106483 & 5475 \\
\hline
\end{tabular}

1 


\section{Table 2 (on next page)}

Summary of genome sequences of SARS-CoV-2 strains isolated in Latin America and collected in GISAID database.

Information updated on April 20, 2020 (Hadfield et al. 2018; Sagulenko et al. 2018). 


\begin{tabular}{|c|c|c|c|}
\hline Country & Submitting lab & Location & Total \\
\hline Argentina & Instituto Nacional Enfermedades Infecciosas C.G.Malbran & Argentina & 3 \\
\hline \multirow[t]{18}{*}{ Brazil } & \multirow[t]{5}{*}{ Bioinformatics Laboratory - LNCC } & Goiais & 1 \\
\hline & & Minas Gerais & 5 \\
\hline & & Rio de Janeiro & 7 \\
\hline & & Rio Grande do Sul & 1 \\
\hline & & São Paulo & 4 \\
\hline & \multirow{3}{*}{$\begin{array}{l}\text { Instituto Adolfo Lutz, Interdiciplinary Procedures Center, } \\
\text { Strategic Laboratory }\end{array}$} & Brasilia & 1 \\
\hline & & Sao Paulo & 2 \\
\hline & & Sao Paulo & 11 \\
\hline & \multirow{8}{*}{$\begin{array}{l}\text { Instituto Oswaldo Cruz FIOCRUZ - Laboratory of Respiratory } \\
\text { Viruses and Measles (LVRS) }\end{array}$} & Maceio & 1 \\
\hline & & Feira de Santana & 2 \\
\hline & & Brasilia & 5 \\
\hline & & Vila Velha & 1 \\
\hline & & Niteroi & 1 \\
\hline & & Rio de Janeiro & 6 \\
\hline & & Florianopolis & 1 \\
\hline & & Joinville & 1 \\
\hline & $\begin{array}{l}\text { Laboratorio de Ecologia de Doencas Transmissiveis na } \\
\text { Amazonia, Instituto Leonidas e Maria Deane - Fiocruz Amazonia }\end{array}$ & Manaus & 1 \\
\hline & Laboratory of Virology & Brasilia & 1 \\
\hline \multirow[t]{3}{*}{ Chile } & \multirow[t]{2}{*}{ Instituto de Salud Publica de Chile } & Santiago & 2 \\
\hline & & Talca & 2 \\
\hline & MSHS Pathogen Surveillance Program & Santiago & 3 \\
\hline \multirow[t]{2}{*}{ Colombia } & \multirow{2}{*}{$\begin{array}{l}\text { Instituto Nacional de Salud Universidad Cooperativa de } \\
\text { Colombia Instituto Alexander von Humboldt Imperial College- } \\
\text { London London School of Hygiene \& Tropical Medicine }\end{array}$} & Antioquia & 1 \\
\hline & & Bogota & 1 \\
\hline \multirow[t]{2}{*}{ Ecuador } & \multirow[t]{2}{*}{ Institute of Microbiology, Universidad San Francisco de Quito } & Pichincha & 3 \\
\hline & & Quito & 1 \\
\hline \multirow[t]{8}{*}{ Mexico } & \multirow[t]{5}{*}{ Instituto de Diagnostico y Referencia Epidemiologicos (INDRE) } & Chiapas & 1 \\
\hline & & Estado de Mexico & 1 \\
\hline & & Mexico City & 2 \\
\hline & & Puebla & 1 \\
\hline & & Queretaro & 1 \\
\hline & $\begin{array}{l}\text { Instituto Nacional de Ciencias Medicas y Nutricion Salvador } \\
\text { Zubiran }\end{array}$ & Mexico City & 5 \\
\hline & Instituto Nacional de Enfermedades Respiratorias & Mexico City & 5 \\
\hline & $\begin{array}{l}\text { Laboratorio Central de Epidemiología-DLVIE / Laboratorio de } \\
\text { Secuenciación-Centro de Instrumentos. Instituto Mexicano del } \\
\text { Seguro Social }\end{array}$ & Chihuahua & 1 \\
\hline $\mathrm{Nepal}^{\mathrm{a}}$ & The University of Hong Kong & Kathmandu & 1 \\
\hline Panama & Gorgas Memorial Institute for Health Studies & Panama City & 1 \\
\hline Peru & $\begin{array}{l}\text { Laboratorio de Referencia Nacional de Biotecnologia y Biologia } \\
\text { Molecular. Instituto Nacional de Salud Peru }\end{array}$ & Lima & 2 \\
\hline Uruguay & Microbial Genomics Laboratory, Institut Pasteur Montevideo & Montevideo & 9 \\
\hline & & Total general & 98 \\
\hline
\end{tabular}

1 aNepal was included due to researchers with Colombian and Honduran affiliations contributed in

2 its genome sequencing (Sah et al. 2020). 